\title{
A PERTENÇA DO SENTIDO ORIGINÁRIO DO AMOR AO HORIZONTE CENTRAL do Pensamento de Martin Heidegger
}

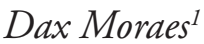

\begin{abstract}
Resumo: Embora ainda sejam escassas as abordagens sobre o amor em Heidegger, tal reflexão pode ser liberada em múltiplos sentidos, sendo objetivo do presente artigo apontar para um deles, talvez o mais abrangente. Para tanto, após introduzirmos breves consideraçóes acerca de trabalhos já existentes, buscamos privilegiar aqui, de início, a centralidade, não do amor como um conceito na obra de Heidegger, mas do sentido do amor em sua própria concepçáo de Filosofia, tal como ele parece assumir. Todavia, a restriçấo a esse aspecto da questão pode fazer com que caia em segundo plano algo mais essencial, a saber, que o amor não apenas traduz a essência da atitude pensante, mas compreende toda a discussáo heideggeriana sobre nosso modo de ser, da qual emerge o problema da Filosofia e a Filosofia como problema. Em seguida, portanto, partimos para a correspondência entre essa consideração mais geral e a questáo das relaçóes de amor entre humanos.
\end{abstract}

Palavras-Chave: Amor. Liberdade. Sorge. Porvir. Favor.

Parece inescapável, a julgar pelos raros estudos que tematizam o amor na obra de Heidegger, apelar às ocorrências da palavra em uma passagem da carta Sobre o humanismo, um trecho compilado nos Seminários de Zollikona resposta de Heidegger a Binswanger - e, naturalmente, à correspondência com Hannah Arendt, que é, certamente, a fonte mais profícua, mas também a utilizada com maior parcimônia. Creio não poder, nesta oportunidade, escapar ao inescapável. De todo modo, o propósito deste trabalho é o de buscar inserir tais fontes em um contexto maior e evitar tomá-las como ponto de partida. Por esse meio, o que dissera Heidegger sobre o amor não há de ser tomado, como uma primeira leitura da obra pode sugerir, como ocorrências casuais, mas como expressôes de um pensar não tematizado pelo autor, mas ainda assim qualitativamente decisivo, na medida em que remete ao essencial do pensar autêntico em geral. Não é possível especular a propósito das razóes pelas quais Heidegger frequentemente omitira a tematização ou ocultara esse

${ }^{1}$ Professor Adjunto no Departamento de Filosofia e do Programa de Pós-Graduação em Filosofia da Universidade Federal do Rio Grande do Norte, Natal, RN - Brasil. E-mail: dax@cchla.ufrn.br

http://dx.doi.org/10.1590/0101-3173.2018.v41n2.08.p137 
elemento do pensar, porém, a adequada seleção e confrontação das raras mençóes, postas em contexto comum, deve ser eloquente e elucidativa, de sorte a reunir as pistas suficientes para lançar luz sobre novas perspectivas e caminhos de pensamento, a partir de então. Decerto, não diretamente no que concerne a temas já consagrados, mas, quiçá, a sua proveniência, que supóe a natureza da atitude pensante bem como o empenho a ela dedicado. Assim, nesta oportunidade, náo poderei me deter no julgamento sobre o velamento do tema por Heidegger e, talvez, de modo relativamente indireto, poderá ficar claro em que medida Heidegger, ainda assim, pode oferecer uma contribuição positiva para a compreensão da relação entre amor e filosofia, enquanto não restrita a uma atitude perante o saber e a verdade, todavia, todo outro em geral e a um outro em particular. Esse caminho que se pretende abrir, contudo, só pode ser percorrido em parte no presente artigo, em virtude mesmo de se tratar aqui, precisamente, da abertura do caminho ou, antes, de sua revelação preliminar, a partir do que ele possa ser mais compreensivamente trilhado por mim mesmo e, espera-se, por outrem. Por isso, não se trata de dizer se Heidegger aborda bem ou mal o tema - seja o sentido do amor, seja o da filosofia e do filosofar -, mas o quáo longe esse tema leva (ou pode levar) nas leituras da obra de Heidegger, as quais, em torno desse tema, ainda são pontuais.

Quanto à parcimônia no uso da correspondência, sabe-se do frequente preconceito a que está sujeita a carta, como fonte filosófica... Não é este o momento apropriado para aprofundar essa discussão, sequer havendo espaço para tanto, mas remeto à abordagem da questáo por Valeria Piazza (2003), em seu $O$ amor em retração, publicado junto de $A$ paixão da faticidade, de Agamben, no livro A sombra do amor: sobre o conceito de amor em Heidegger. ${ }^{2}$ Sobre isso, apenas citarei as palavras de Benjamin, em uma carta a Ernst Schoen, de 19 de setembro de 1919:

As trocas de cartas são muito subestimadas porque referidas à noção inteiramente falaciosa de obra e autoria uma vez que pertencem à esfera do "testemunho", cuja referência a um assunto é tão insignificante quanto a referência a qualquer testemunho histórico-pragmático (inscrição) sobre a pessoa de seu autor. (BENJAMIN apud PIAZZA, 2003, p. 77).

Seja por essa razão ou por qualquer outra, o fato é que recorrer a cartas para discutir filosoficamente um assunto não é algo tomado como atitude

2 Uma tradução minha para essa obra encontra-se no prelo. Eu a utilizarei aqui, embora fazendo referência à edição originalmente publicada em francês, conforme a bibliografia. 
"cientificamente" séria. O preconceito se agrava, quando se recorre a cartas em virtude do fato de o autor não haver discutido certo assunto, em sua obra canônica. Que isso, no caso do amor em Heidegger, é uma imprecisão atestam as passagens constantes na compilação de Medard Boss, não sendo à toa que por aí começam o próprio Agamben (2003), Ferreira (2011), Fernandes (2011) e, em um verbete, Schuback (2015). Ponho em destaque "as passagens", porque apenas a uma delas se faz referência, nesses trabalhos, a que revela a Sorge como amor, retirada do manuscrito de 8 de março de 1965 (HEIDEGGER, 2009, p. 227). A segunda passagem é de um seminário ocorrido na casa de Boss, em 23 de novembro do mesmo ano, na qual se lê que

o mal-entendido de Binswanger náo consiste tanto em que ele quer complementar o "cuidado" com o amor, mas sim no fato de que ele não vê que o cuidado tem um sentido existencial, isto é, ontológico, que a analitica do Dasein pergunta pela sua constituiçāo fundamental ontológica (existencial) e não quer simplesmente descrever fenômenos ônticos do Dasein. (HEIDEGGER, 2009, p. 154-155).

Considerando que Ser e tempo apresenta o Dasein como ser-no-mundo como Sorge, se Sorge é inseparável do amor fundado na compreensão do ser, não como mero fenômeno ôntico, pode-se mesmo concluir não apenas que o amor tem, sim, lugar em Ser e tempo, mas até, nas palavras de Schuback, que "Dasein é amor" (SCHUBACK, 2012a. p. 138-139). É o resultado a que ela chega, ao comentar a referida passagem do manuscrito de 8 de março, em seu $O$ amor heideggeriano. É precisamente a partir do manuscrito de Zollikon que os mais preciosos desdobramentos tiveram lugar e, felizmente, cada um dos estudos referidos acima seguiu seu próprio caminho, sem se repetirem ou citarem uns aos outros, exceto no caso de Agamben, o qual é citado por Piazza, Ferreira e Schuback. Isto é importante: o fato de os estudos dos brasileiros terem - ao menos até aqui - se desenvolvido de modo independente. Contudo, isso confere às tentativas um certo grau de indesejável marginalidade ao tema. Nesse contexto, iniciar a discussão pelos Seminários adquire certo tom "apologético" e autoindulgente, facilmente quebrado, quando cada um dos autores consegue seguir a pista deixada em Zollikon, para vislumbrar o sentido e o lugar do amor, na obra de Heidegger, que supera em muito o que nos oferece a carta Sobre o humanismo. Sim, esta também uma carta, mas teria, talvez, deixado de sê-lo, ao ser publicada pelo próprio Heidegger, em uma coletânea tão relevante como Marcas do caminho. Novamente, no que concerne a cartas, o próprio Heidegger, em uma carta tardia a Arendt, com data de 29 de setem- 
bro de 1967, levanta uma questão mais relevante do que as que comumente se colocam: "Nas cartas espelha-se a obra... ou será que vale antes o contrário?" (HEIDEGGER apud LUDZ, 2001, p. 116 [Doc. 98]). É notável que Heidegger não ponha em dúvida se se trata a carta de algo relativo à "intimidade", à "esfera privada"; trata-se de questionar se a vida se reflete na obra ou se a obra se reflete na vida, sem, contudo, pensá-las como separadas! A vivência se reflete no pensamento ou o pensamento se reflete na vivência, quiçá ambos, mas jamais se separam. A separação é meramente teórica, artificial, e isso está em pleno acordo com o pensamento de Heidegger.

Diante desse cenário, a reflexão sobre o amor em Heidegger pode ser liberada em múltiplos sentidos, buscando-se aqui privilegiar, de início, a centralidade, não do amor como um conceito na obra de Heidegger, mas do sentido do amor em sua própria concepção de Filosofia. Nisso consiste um primeiro momento. Todavia, a restriçáo a esse aspecto da questão pode fazer com que caia em segundo plano algo mais essencial, a saber, que o amor não apenas traduz a essência da atitude pensante, mas compreende toda a discussáo heideggeriana acerca de nosso modo de ser, da qual emerge o problema da filosofia, do ser, da verdade e do movimento. Por uma questão metodológica, não por "amor" da letra, busco assumir o que Heidegger exprime, a fim de contextualizar em seus textos, tấo adequadamente quanto possível, suas palavras sobre o amor. $\mathrm{O}$ amor é originário, no seguinte sentido:

No amor, surge sempre a responsabilidade pelo ser amado, o ser com o qual cada um de nós é e está no modo da preocupação [Fürsorge]. [...] o amor não deve ser concebido como relaçáo fatual entre dois ou mais entes que se ocupam cotidianamente uns dos outros [como meras subjetividades] mas sim como modo próprio de ser daquele que é no mundo como cura [Sorge]. [...] o amor é cura, débito e angústia - [...] um modo de ser co-pertinente à cura, fundamento de toda preocupaçáo. [...] Portanto, o cuidado [tal como entendido psicológica ou antropologicamente] náo determina o amor, mas, ao contrário, é este a determiná-lo no mundo das ocupaçóes. (MORAES, 2005, p. 68-69).

Os problemas clássicos da metafísica têm sua originariedade elucidada mediante a investigação que segue o fio condutor da "questão fundamental da filosofia", no dizer de Heidegger (2012), em seu curso sobre A essência da liberdade humana. Tal investigaçáo encontra seu caminho no problema da liberdade e é precisamente à liberdade que vemos vinculado o amor, naquilo que nos legou Heidegger e conforme destacado por aqueles já 
referidos pesquisadores, os quais se questionaram a respeito, cada qual a seu modo. A recondução do amor à Sorge, todavia, pode levar muitos a pensar que isso mais uma vez deve restringir o alcance da questão ao âmbito do assim dito "primeiro Heidegger" ou, no máximo, ao "período de transição". Quanto a isso, recorrer a trechos breves dos Seminários (em que Heidegger fala de Ser e tempo) ou à carta Sobre o humanismo e escritos dos anos trinta, estimados como "de transição", pode parecer pouco eloquente. A "solução" seria, talvez, recorrer a alguma fonte "pós-virada", que nos "autorizasse" o movimento de, a partir do amor como liberdade, lançar luz náo apenas sobre o pensamento de Heidegger como um todo, mas, além disso, trazer à proximidade da existência propriamente concreta e imediata o sentido do amor que abarca todos os níveis da vivência humana. Dito de modo breve, a compreensão do amor como a disposição fundamental e essencial ao ser-livre como tal, considerando a centralidade da liberdade como questáo que perpassa toda a obra de Heidegger, consiste no pré-requisito para a possibilidade de se reconhecer, nessa obra, a presença perene do amor.

Como se sabe, o problema da metafísica é aquilo que move toda a filosofia heideggeriana. Indo às raízes da metafísica, a cada vez Heidegger encontra os gregos. Em uma célebre conferência proferida em 1955, diz Heidegger acerca de um fragmento de Heráclito:

O elemento específico de philein [amar] do amor [...] é a harmonia que se revela na recíproca integração de dois seres, nos laços que os unem originariamente numa disponibilidade de um para com o outro. [...] O corresponder é, necessariamente e sempre e não apenas ocasionalmente e de vez em quando, um corresponder dis-posto. (HEIDEGGER, 2000a, p. 32-37).

Como compreender adequadamente essa "disponibilidade correspondente"? A que ela se volta, em primeiro lugar? Naturalmente, ao que é digno de amor. O que é digno de amor, o amável por excelência? Heidegger responde, em um manuscrito do final dos anos trinta: "O digno de amor denomina a palavra a 'sabedoria'." (HEIDEGGER, 2010, p. 62 [\$14]). Note-se que o digno de amor não é a sabedoria, que não se trata a Filosofia de uma mera inclinação por um objeto nomeado "sabedoria" por aquele que a deseja para si como a um bem; ao invés disso, o amor é próprio à sabedoria. Em conferência proferida em 1952, Heidegger parafraseia Hölderlin, assentindo: "Consideramos que o amor se funda no fato de pensarmos o mais profundo." (HEIDEGGER, 
2007a, p. 120). O amor da sabedoria não é um sentimento despertado por um objeto, mas é "elemento" copertinente ao "mais profundo" - a sabedoria mais profunda é aquela em que há amor, sendo junto ao amor que esse saber se realiza, na condição de "disponibilidade correspondente". Nas palavras de Schuback (2012b, p. 72):

Vendo claro a precedência da sabedoria da amizade relativamente à amizade pela sabedoria, os gregos prezaram mais do que tudo pensar com amigos, pensar junto, descobrindo nos banquetes, nos "simpósios", como se diz em grego, a alegria da vida filosófica, a vida de pensar entre amigos a amizade pelo que nos dá e nos faz pensar.

A metafísica insistiu em buscar para o amor um objeto digno - a negação da temporalidade, a negação da mortalidade, a negação da finitude, em uma palavra, o divino. Tornando-se o divino um objeto, assim também o amor. ${ }^{3}$ Esqueceu-se, porém, de atender ao divino, de que o homem deveria antes ser o que é, ao invés de querer ser-outro. A humanidade empenhou-se em querer ser digna de amor, como se à realização do amor coubessem condiçóes, como se, por ele, algo se devesse fazer. A isso retornarei mais adiante, porém, por ora, esse "nada a fazer" serve de elucidação inicial para a "disponibilidade correspondente", no sentido da gratuidade. Na conferência de 1951, ... poeticamente o homem habita..., quase no final, Heidegger diz que "amizade" é "uma extraordinária tradução feita por Hölderlin do termo kháris" e, citando um verso de Sófocles, em que a kháris é traduzida por "benevolência", conclui que o advento da benevolência/amizade genuína - o bem-querer gratuito encerra "a felicidade de medir-se com o divino." (HEIDEGGER, 2007b, p. 180). Comentando essa passagem, Fernandes afirma, com razão, que a gratuidade, graças a cujo modo de ser se dão dileção e benevolência, "é o modo de ser originário, fontal, do cuidado.” (FERNANDES, 2011, p. 169). O espaço disponível aqui impede o aprofundamento histórico do conceito de kháris, mas logo se perceberá o quão distante se encontra de seu sentido originário o afeto compassivo a que ordinariamente se remete a caritas cristã e o quão tal sentido abre caminho à compreensão do amor, em Heidegger.

A “disponibilidade correspondente" é análoga àquela do ouvinte - não qualquer ouvinte, porém, o ouvinte genuíno de que nos fala Ser e tempo-, pois a Filosofia não acontece apenas na fala, mas também na escuta. "Mas como

\footnotetext{
${ }^{3}$ Essa questão é tratada criticamente e, em detalhe, em meu livro História filosófica do amor: ensaio para uma nova compreensão da essência do amor humano, atualmente no prelo.
} 
surgem aqueles que ouvem?” - perguntava-se Heidegger (2010, p. 60), no citado manuscrito do final dos anos trinta - "somente aqueles que podem eles mesmos dizer podem ouvir, sem que se tornem ao mesmo tempo servos por isso". Uma vez que nessa experiência amorosa do saber enquanto ser-ouvinte com algo a dizer, que se dispóe como aquele que responde, e por isso livre, há sempre uma contraparte, a "responsabilidade" do falar e ouvir é sempre uma co-respondência. $\mathrm{O}$ deixar-dizer no silenciar daquele que, não tomado pelo falatório circundante, tem o que dizer, consiste na positividade da liberdade, que jamais se realiza no mero querer-falar do falatório.

Mediante essa tentativa de elucidação da "disponibilidade correspondente" como capacidade de estar aberto ao outro, no deixar-dizer, chega o momento de citar a recorrente passagem da carta "Sobre o humanismo", pois agora a ligação essencial entre o amor e a liberdade como deixar-ser é, decididamente, explicitada. Zelar "por uma 'coisa' ou por uma 'pessoa', em sua essência”, diz Heidegger (2008a, p. 329), "significa amá-la, querê-la” - "sie lieben: sie mögen”, lê-se no original. ${ }^{4}$ Todavia, esse querer (mögen) não pertence ao domínio de uma vontade que "só pode produzir isto ou aquilo, mas pode fazer com que alguma coisa 'se essencie' em sua pro-veniência", deixando que ela seja, consistindo na "verdadeira essência do ser capaz [Vermögens]". Esse

${ }^{4}$ Ver também o fino comentário de Marcia Schuback (2012a, p. 146-147), em seu Heideggerian love, bem como suas alternativas de tradução, lidando com a riqueza semântica do verbo mögen. Vale salientar a imensa dificuldade existente em se traduzir o trecho, náo apenas em virtude do complexo semântico reunido em mögen, que por si só pode trazer embaraços ao intérprete e merecer um ensaio à parte. Algo que, por exemplo, pode causar estranhamento é verter, como faz Agamben, a preposição kraft pelo substantivo grâce: por que Agamben teria deixado passar a oportunidade de lançar mão de uma expressão como "por força de"? Na tradução brasileira temos "em virtude de" e a versão inglesa traz o substantivo strength. De fato, "por força de" evoca a noçâo de necessidade (por causa de), o que evidentemente não é o caso, razão mesma pela qual a palavra aparece entre aspas. Tal desvio é evitado por uma alusão a uma expressão aparentemente sinônima, porém dotada de sentido muito diverso: "graças a". Ao invés de se tratar de uma necessidade, trata-se de algo que advém por favor, pelo livre querer de alguém, sem o que algo não se realizaria, sendo, portanto, uma espécie muito peculiar de "causa" - é, antes, uma proveniência da possibilidade de que algo seja, possibilidade esta que não se encontra jamais em nosso poder ao mesmo tempo em que não se dá como coerção, mas exclusivamente por favor, ou mesmo "por acaso". É do possível que qualquer coisa como uma causa pode provir. Nesse sentido, strength pode ser uma boa opçâo, pois a força suficiente para que algo seja possível dispensa que se recorra a uma ordem causal prévia, como quando se diz "obra da graça". Desse modo, "graça" pode ser entendida em sentido substantivo, pois o favor é também um dom, um presente (kháris) - mögen é aqui pensado como "presentear a essência", razão pela qual Schuback utiliza a tradução favouring. "Favor" e "graça", ademais, são palavras traduzíveis por amor, particularmente quando se trata do amor caritativo, ágape, o que faz recordar a remissão a Agostinho por Arendt, e vemos aqui o próprio Heidegger apontar para lieben e mögen como termos intercambiáveis. Por essa via, acaba ocorrendo um contato entre a versáo de Agamben e aquelas que traduzem Vermögen por "ser/tornar capaz" em vez de "potência" (puissance). 
poder (Vermögen) próprio ao querer, que é uma capacidade, não uma força dominadora, é aquilo em "virtude" de quê "alguma coisa pode propriamente ser", "é o 'possível' [Mögliche] em sentido próprio". Em todo esse contexto, o poder não quer dizer um poder-fazer, mas um poder-ser, ou mesmo um poder-deixar-ser, assim como o querer não é um desejar para si, mas um liberar para o próprio. $\mathrm{O}$ pensamento autêntico, amoroso por sua própria essência, é ouvinte e, como tal, acolhedoramente liberador de possibilidades de ser, não se confundindo a um uso instrumental e instrumentalizador da racionalidade pelo qual se pretende apenas determinar e condicionar os modos de ser restringindo e fechando suas possibilidades - é à ciência e à técnica que cabe realizar possibilidades; ao amor, permiti-las. Afirma Heidegger, mais adiante (p. 330): "A assim chamada 'existência privada' ainda não é, em todo caso, o ser essencial, livre, do ser humano" pelo simples fato de se ver ocupada "livremente" com seus próprios interesses; pelo contrário, uma tal existência apenas "se aferra à negação do âmbito público", mantendo-se, todavia, como "apêndice dependente" que se "alimenta de seu mero retirar-se do público". Trata-se, em verdade, de uma fuga da própria responsabilidade e do amor o que impossibilita essencialmente o pensar - isto é, uma fuga do estar abertamente disposto, atento e pronto a responder ao apelo uma vez ouvido.

Sendo essa uma passagem recorrente nos estudos referidos sobre o amor em Heidegger, não é possível aqui retomar em detalhes os resultados a que cada um chegou, mas algumas indicações devem ser feitas. Ferreira, ao fim de seu artigo Amor e liberdade em Heidegger, salienta:

Encarregar-se de alguém não significa ser em seu lugar, assumir os seus cuidados ou conservar este alguém para si, antes significa doaçáo de ser, ou seja, gratuidade em desdobramentos de liberação de possibilidades de ser [...]. Isto significa empenhar-se conjuntamente para que cada um seja livre para ser o que propriamente se é. [...] Neste tipo de empenho fica em suspenso os modos impróprios da afinaçáo do amor, melhor, neste empenho está suspenso o controle sobre o modo de ser do outro, a cobrança que o outro seja deste ou daquele modo e a barganha ou o comércio de possibilidades de ser. Com esta suspensáo temos o encarregar-se de alguém no modo do empenho livre para ser o que se é, ou seja, temos o modo próprio da afinação do amor. (FERREIRA, 2011, p. 157).

Em Ser e tempo, à luz dessas palavras, reconhecemos claramente a que possibilidade da preocupação corresponde o amor autêntico da kháris. Em Ser e tempo, $\$ 26$, dentre os modos positivos da preocupação, há aquele que 
evita que o outro seja em sua propriedade, buscando ser em seu lugar nas ocupaçóes. Trata-se do einspringen. Essa atitude exacerbadamente cuidadora domina o outro pela dependência, mantendo-o incapaz, como se ele não pudesse ser por si mesmo, calando seu cuidado essencial. É o que comumente se entende por "superproteção". O outro modo positivo se encontra expresso pela palavra vorausspringen. Essa espécie de preocupação consiste em que não se substitui ou tenta substituir o outro em seu ser e suas possibilidades de fato, retirando-lhe seu cuidado, mas o devolvendo, ou seja, sem indiferença, contribuindo para seu ser-capaz. Eis a atitude amorosa para com o outro, que Heidegger (2014, p. 179) afirma ser, "em sua essência, [a que] diz respeito à cura propriamente dita, ou seja, à existência do outro e não a uma coisa de que se ocupa". Nessa atitude, ajuda-se "o outro a tornar-se, em sua cura, transparente a si mesmo e livre para ela”. Portanto, amar não é estar disponível como quem presta um serviço, não é dedicação a algo superior, mas a proteção que visa à elevaçáo do amado, no sentido da realização de suas possibilidades, próprias ou impróprias, sejam elas de nosso gosto ou não - por isso se diz que a preocupação genuinamente amorosa é gratuita. Assim se pode compreender o que se lê no $\$ 14$ de seu manuscrito póstumo, reunido sob o título Meditação: "Amor é a vontade de que o amado seja, na medida em que ele encontra o caminho para a sua essência e se essencie nesse caminho. Uma tal vontade não deseja nem exige. Dignificando, ela deixa que o que é digno de amor 'venha a ser' como o amado, sem, não obstante, criá-lo.” (HEIDEGGER, 2010, p. 62).

Remetendo-se a uma carta de Heidegger e Arendt, escrita em 22 de junho de 1925, concluem Lancelin e Lemonnier (2009, p. 161), citando-a ${ }^{5}$ :

Amar [...] é "apreender o 'tu' deixando-o ao mesmo tempo ser, isto é, sem procurar possuí-lo. Abandonados ao que nos supera, não podemos nos apropriar completamente dessa doação que nos é feita, mas apenas acolhêla. "Que o amor seja, eis o regozijante fardo de que a existência é legatária, a fim de que, por sua vez, ela possa ser".

Mas o que significa exatamente "apreender o 'tu', ou melhor, como seria isso possível? Minha sugestão seria que tal possibilidade advém da abertura liberadora que os olhos do amor efetivam e, nesse sentido, poder-se-ia ler o que diz Heidegger, em um de seus cursos sobre Nietzsche, intitulado A vontade de poder como arte: "O amor nunca é cego, mas clarividente; somente o estado daquele que está enamorado [Verliebtheit] é cego, fugidio e

\footnotetext{
${ }^{5}$ Heidegger, citado conforme as autoras.
} 
brusco." (HEIDEGGER, 2007c, p. 45). Decerto, há muito dessa "cegueira" no enamoramento "cheio de cuidados", mas não no amor propriamente dito, essencial. Como frisa Ratcliffe (2009, p. 361), o "amor que é 'cego' é um amor pelo qual alguém experimenta o mundo, um amor no qual se está esquecido [oblivious] de certas possibilidades", mas tal não seria, como veremos, o caso do amor que deixa-ser. Voltando à carta de 1925, também se lê que amor é fé, confiança no outro, sendo por essa abertura que se torna possível "apreender o tu” tal como ele é e será:

Se digo que minha alegria para consigo é grande e cresce, entáo isso significa que também acredito em tudo o que faz parte de sua história. Não arranjo para mim um ideal, nem tampouco estaria em condiçóes de me sentir tentado algum dia a educá-la ou coisas do gênero, mas a amo completamente. Exatamente como você é e com a história que permanecerá a sua. Somente entáo o amor também tem força para o futuro e não se confunde simplesmente com o gozo fácil de uma ocasiáo; somente então a possibilidade do outro está co-inserida e fortemente instaurada contra crises e lutas que náo permanecem ausentes. Mas com isso uma tal crença também está protegida contra o abuso de confiança do outro no amor. $\mathrm{O}$ amor que pode se lançar alegremente em direção ao futuro finca raízes. (HEIDEGGER apud LUDZ, 2001, p. 26 [Doc. 20]).

Logo, amor não é apenas amor de algo imediatamente presente, entretanto, originariamente, amor do porvir. Assim se pode perceber com suficiente clareza uma unidade de pensamento em textos de diferentes épocas, sejam pertencentes à obra, sejam pertencentes à correspondência privada, seja no que concerne à filosofia, seja no que concerne à vivência do amor de alguém. O deixar-ser não é pertinente apenas ao humor sereno, mas ao amoroso, e talvez mais originariamente, como disposiçâo, uma vez que o amor copertence à liberdade essencial. Não é, portanto, somente uma afinação privilegiada na lida com o aparato técnico ${ }^{6}$, mas inerente a todo estar-junto, inclusive e sobremaneira no amor. A propósito, é possível libertar-se das inquietas ocupaçóes pelas quais se tenta, obstinada, egoística e narcisicamente, conformar o amado a expectativas do amante, como se o próprio amante não devesse, também, ser "passível de mudanças". Esse já é um tema recorrente nas primeiras cartas de Heidegger a Arendt, como, por exemplo, na escrita um pouco antes, em $8 \mathrm{de}$ maio, na qual ele se pergunta:

${ }^{6}$ V. Heidegger, [2000b]. 
Tudo já não tinha se dado e não será sempre assim? Fizemos algo para que isso acontecesse?/ E o que podemos fazer além de nos abrirmos: além de deixarmos ser o que é [?] Deixar ser de um tal modo que o amor se torne para nós uma alegria pura e a fonte de cada novo dia de vida. (HEIDEGGER apud LUDZ, 2001, p. 21 [Doc. 14]).

Heidegger chega a afirmar ter apreendido isso de Agostinho, segundo a formulação "Amo: volo, ut sis" . ${ }^{7}$ A formulação encontrará seu lugar no terceiro capítulo da segunda parte da tese de Arendt, no contexto em que ela escreve: "O amor renuncia ao outro para o provocar para avançar em direção ao seu ser verdadeiro, tal como tinha renunciado a si próprio na procura de si próprio." (ARENDT, 1997, p. 116). Na carta em questão, de 13 de maio de 1925, Heidegger escreve: "Estar em meio ao amor [in der Liebe sein] = ser impelido até o seio da existência mais própria. [...] Eu a amo: quero que você seja o que é." (HEIDEGGER apud LUDZ, 2001, p. 23 [Doc. 15]). O comentário de Piazza coloca em destaque:

A posição ontológica do amor é finalmente confirmada aqui: estar no amor equivale pura e simplesmente a experimentar a existência mais "própria" e a descobrir, concomitantemente, que esse ser "compelido" no seio da existência também significa querer a existência do outro. (PIAZZA, 2003, p. 90).

Já o caráter desse ser compelido (ou impelido) pelo amor consiste naquilo que Heidegger denominará "paixão", no referido curso sobre Nietzsche, no qual Agamben encontra o ponto central de sua interpretação de que o amor, em Heidegger, é "paixão da faticidade". É, no entanto, desejável e mais do que isso! - necessário pensar tais palavras contra Agostinho e para além dele, no seguinte sentido: amor como superação do desejo de posse - a única renúncia legítima. Permite-se assim que cada um seja o que é. E isso não é válido apenas para relaçóes de amor propriamente dito, uma vez que, nas palavras de Schopenhauer (2009, p. 200), na $21^{\text {a }}$ de suas Parêneses e máximas, "para vivermos entre os homens, temos de deixar cada um existir como é, aceitando-o em sua individualidade ofertada pela natureza, náo importando qual seja”. Que o amor/cuidado é modo propriamente originário de toda abertura - isso significa: a liberdade essencial -, Heidegger já antecipa no início da década de

\footnotetext{
${ }^{7}$ Cf. carta seguinte, p. 23.
} 
vinte, inscrevendo em adendo a um de seus cursos: "O cuidar é sentido fundamental da relação de vida.” (HEIDEGGER, 2011, p. 112).

Que o amor, enquanto modo mais próprio da preocupação, na medida em que tem em vista o ser-livre-para de um outro, assume e quer seu porvir, justifica-se pela própria essência do cuidado radicada na temporalidade de ser-no-mundo. Nas palavras de Fernandes (2011, p. 164), a "cada instante, a presença é o seu porvir, o seu ter-sido e o seu presente", de maneira que o "deixar-ser que faz emergir as coisas em sua propriedade" deve ser compreendido como "a forma de compreensão originária das coisas." Aí se encontra a essência da liberdade humana, segundo Heidegger (2012, p. 343), no curso em que a tematiza - é a condição de possibilidade da manifestabilidade do ser do ente, da compreensão do ser.

Parece oportuno, a esta altura, fazer referência a uma das definições oferecidas por Heidegger para o verbo freien ("liberar") - que também pode ser traduzido por "namorar" ou, antigamente, por "pedir em casamento" -, a qual, aliás, guarda grande proximidade à sua recém-aludida caracterização do apego amoroso à essência, na carta Sobre o humanismo. Enfatiza ele: "Significa, originária e propriamente: defender, deixar algo repousar em sua própria essência protegendo-o." (HEIDEGGER, 2006, p. 108-109). Propositadamente, não sigo a opção da edição argentina adotada, vertendo o verbo schonen para o espanhol preservar, a fim de escapar a conotaçóes que, com certeza, também Heidegger quereria evitar. Minha opção por "defender" responde por conotaçóes que remetem ao cuidado (em amplo sentido) e à proteção - palavra de que já me utilizei para caracterizar o modo da preocupação vorausspringen - não apenas inerentes ao sentido do verbo alemáo como também explicitadas pelo próprio Heidegger, na sequência: "Mas proteger é: manter a essência no cuidado em que só se demora se se lhe permite retornar ao repouso de sua própria essência. Proteger é: ir constantemente em socorro desse repouso, esmerar-se nele.” Pela mesma razão indicada, não segui o espanhol retener, em vista de suas conotaçóes de "retenção" inerentes a todo "conservar" de fato, o que não é o caso, já que o protegido permanece evidentemente livre, em sua essência, sob a proteção cuidadora, não sendo, pois, "mantido" no sentido de permanecer em um estado, porém, pelo contrário, na dinâmica de seu ser-possível. ${ }^{8}$ Assim, a constância é exigência de quem cuida, não do que é cuidado, que só permanece enquanto é livre, se não escaparia, justamente

\footnotetext{
${ }^{8}$ É possível que Fernandes (2011, p. 170) tenha tido o mesmo cuidado, ao empregar os termos "custodia e salvaguarda".
} 
porque, cuidando do amado, é do próprio amor que se cuida, e o amor reside no dar, não no receber, sendo a reciprocidade uma feliz co-incidência, no rigor da expressão - a incidência conjunta de dois na relação que os liga entre si, sob a forma de um duplo cuidado, não de um cuidado que se oferece e se tem de volta. Eis por que toda dominação ou controle é repelente do que se pretende dominar e, portanto, nisso reside o sentido da incompatibilidade entre amor $e$ poder e o da coincidência copertinente de liberdade e amor. Por sua vez, o verbo "manter", no sentido aqui pretendido, abre espaço à ideia de um cuidado que tem em vista, na manutenção, garantir apenas que persista o vigor do que é mantido, o sentido de todo cuidado que vai em socorro. Em semelhante sentido se poderia falar em uma alegórica relação de maternidade da parte de Afrodite para com Eros, a beleza como nutriz-mantenedora do amor.

Com respeito ao vigor e sua manutenção, a deusa da juventude no paganismo germânico chamava-se Freya - era ela, deusa também da fertilidade, do amor e da beleza e cujo nome segue a etimologia de "liberdade", Freiheit, a cultivadora das maçãs de ouro que garantiam a imortalidade dos demais seres divinos. Assim, pensar o amor como liberdade é pensar o amante como abrigo acolhedor para o amado. A propósito, a palavra alemã que Heidegger usa aqui para "cuidado" é Hut, homógrafa do termo alemão para "chapéu", que, em inglês - também uma língua germânica -, virou hat. Em inglês, hut significa "cabana” - em alemão, Hütte. A proximidade significativa entre essas palavras é bastante visível e nada casual: a cobertura de uma cabana assemelha-se a um chapéu, além de desempenhar o papel de, cobrindo, proteger e defender das intempéries o que se encontra sob si (de minha parte, eu igualmente vincularia a essas imagens a palavra inglesa para "abraço", hug). Também em latim se verifica essa associação, pois tegere significa "cobrir", "abrigar”, "proteger”, e tegum, "telhado" - talvez nossa palavra "telhado" tenha vindo daí, após algumas transiçôes fonéticas. A partícula "pro" do "proteger" - em que se reconhece o tegere latino - indica ao mesmo tempo o caráter antecipatório da defesa que abriga, em que o protetor já se póe disponivel para outro, em correspondência com ele, ao invés de querer ter o outro disponivel para si em uma unilateralidade, e, ainda, que essa antecipaçáo, sendo sempre em prol, em vista de um outro por amor do outro -, náo se antecipa à sua presença, mas é sempre junto dela, coincidindo no instante de seu acontecer, pois a ela se destina. Uma vez que freien carrega, sobretudo, a ideia de algo aberto, esse abrigo não aprisiona, essa defesa não reprime, a manutenção não retém, a cabana não tem portas trancadas. À parte o fato de a imagem da humilde cabana sem trancas do campo consistir em imagem bastante recorrente e evocativa do pensamento de Heidegger, "o 
filósofo da Floresta Negra”, é notável o universo semântico que permeia suas palavras sobre a proteção do livre, palavras que se fundem de modo táo harmônico que, em seu fundo, vibram em uníssono, sinfonicamente.

Outra observação que se faz importante é sobre o caráter originalmente ingênuo e inocente do pro-teger amoroso, isto é, aquele que nâo se antecipa à presença do protegido, no sentido do einspringen. Certo de si mesmo, como o são toda ingenuidade e toda inocência, trata-se de amor seguro que, oferecendo segurança, não conhece o perigo, e por isso libera. Não há nele qualquer malícia. Apenas de modo derivado a defesa de que se ocupa o protetor é uma antecipação de um perigo inatual, seja de todo ausente, seja já iminente, pois é segundo a experiência do risco e da força exterior, segundo um sentimento de todo alheio ao amor - a saber, de des-confiança -, que o defensor se converte naquele que procura se pre-venir (chegar antes) de um dano pre-visto qualquer. Nesse último caso, ao defender, o defensor ocupa-se menos do defendido do que daquilo de que pre-tende defendê-lo; nessa ocupação, o defendido pode ser até "esquecido" enquanto se mantém uma vigilância atenta ao que se passa alhures. Tal defesa, a qual parece ilustrar um caso do modo da preocupação como einspringen, pode até mesmo dar as mãos ao aprisionamento, como em um estado de sítio, em uma quarentena, sob um toque de recolher etc., mas também em todo tipo de restriçôes estabelecidas "para o nosso próprio bem".

Naturalmente, esse último caso faz recordar $A$ peste, de Camus - não tanto pelo isolamento geográfico politicamente imposto, mas por suas consequências existenciais. Penso, em particular, em Raymond Rambert, o jornalista estrangeiro que faz de tudo para escapar do território sitiado, não apenas, como tantos outros, para salvar a si mesmo, todavia, para reencontrar e cuidar da esposa que, muito doente, poderia vir a falecer enquanto ele era detido ali sem notícias. Conta o narrador que "durante todo aquele tempo ele havia de algum modo se esquecido de sua mulher para dedicar-se inteiramente à busca de uma abertura nos muros que o separavam dela", dando-se conta disso apenas no momento em que viu "todas as rotas uma vez mais fechadas", graças a que "ele a reencontrou de novo no centro de seu desejo." (CAMUS, 2005, p. 145). O fracasso da desgastante insistência em escapar, a frustração decisiva de seus planos, eis o que lhe tirou a venda dos olhos, permitindo-lhe ver de novo o verdadeiro objetivo de seus esforços - a mulher amada. Não basta, portanto, que o amado seja o fim último de nossas açôes se, ao nos dedicarmos a ocupaçôes, ainda que em seu nome, ele se torna mero fim, mero nome e, então, "esquecido" uma vez terminado o perigo, correndo-se o risco de, tendo o amante 
reunido todas as provisóes e oferendas necessárias ou simplesmente desejadas para prestar-lhe honras, não houver mais quem as receba. Afinal, nesse ponto, paradoxalmente, o fim e sua efetividade são sacrificados aos meios disponíveis. Aqui se pode reconhecer, em toda sua extensão, a falha essencial de toda dedicação - dedicar-se ao que se ama envolve sempre, ao mesmo tempo, abandono do que se ama em prol de alguma espécie de serviço; eis o que significa dedicação: serviço e separação; jamais amor. A exigência de "amor $e$ dedicação" é uma demanda que destrói a si mesma, consistindo na insana tentativa de dar atenção a dois objetos ao mesmo tempo, enquanto apenas um pode estar em primeiro plano presente a nós.

Semelhante contraste entre expressôes distintas da preocupação, mesmo em seus modos positivos, deve facilitar a compreensão de algo peculiar e ainda silenciado, a saber: que deixar-ser o outro suas próprias possibilidades pode implicar "perdê-lo". "Perdê-lo" não para um rival, não para o desamor, náo para a morte, sequer, mas para ele mesmo. Tal possibilidade parece ir na contramáo de tudo o que se pretendeu dizer, em filosofia ou náo, sobre o amor: "O desejo de ter sempre junto a si." Pode servir como elucidação o que conclui Piazza (2003, p. 101) acerca do que seria a essência do amor para Heidegger: "A essência do amor não pode ser experimentada senão aceitando-se o inadmissível que nos escapa e abandonando-nos a ele." No contexto dessa conclusão, ela acabava de dizer:

Afirmando implicitamente que o amor consiste em manter-se em presença de uma ausência, [Heidegger] não quer dizer com isso que seja necessário dissolver a ausência na presença, lançando sobre ela um raio de luz que a exponha e a revele. Inversamente, manter-se em relação com o oculto tampouco significa deixar-se atrair por ele e permitir que todas as coisas se tornem obscuras. A dimensão de claridade-obscuridade e de opalescência aberta pelo amor, de que a a-létheia é a metáfora mais luminosa, equivale à condição em virtude da qual somos entregues àquilo que nos ultrapassa, àquilo de que não podemos nos apropriar nem compreender por completo, somente padecer.

Quando alguém ama sem ser correspondido, pode-se sustentar que é um amor incondicional, porque a ausência de retribuição nada significa para o amor feliz por amar, o que é muito diferente de querer dar mesmo que o outro não queira receber - isso pode ser outra coisa bem diferente de amor, variando desde a indiferença da dádiva à mera obstinação em se fazer visível, notado. Nesse último caso, não há uma relação propriamente dita, enquanto naquele 
há uma relação, embora de mão-única, como, aliás, sempre é toda relação amorosa. A felicidade por amar se aproxima mais do que escreve Heidegger a Arendt, na já citada carta de 22 de junho de 1925: "Nós só atuamos, conquanto estejamos em condições de dar; sendo indiferente se esta doação é sempre a mesma ou se ela será em geral acolhida." (HEIDEGGER apud LUDZ, 2001, p. 26). O amor verdadeiro não apenas prescinde de provas, como também de contrapartida, de modo que a alegria em presentear apenas aumenta a partir de si mesma, como em uma espécie de "inchaço" - não é paga nem pagável pelo agradecimento -, e toda eventual contrapartida é somada ao próprio amor, que a incorpora em si - náo constitui sua recompensa (toda recompensa é compensação, um crédito para saldar um débito). Esse "inchaço", que também se sente na "incorporaçáo" do amor recebido - não em retorno, não em troca, mas dado em mão-única, independentemente do que quem dá recebera antes, daí chamar a isto co-incidência, a incidência concordante de duas ou mais casualidades -, corresponde a uma sensação ao mesmo tempo vaga e inconteste de que algo em nós infla, de que inflamos de fato e que isso pode ser visível para quem está por perto. $\mathrm{O}$ amor se fisiologiza. Normalmente, essa sensação se confunde com um sentimento de excitação e diz-se que os olhos chegam a brilhar. Entretanto, o mais importante aqui náo é o efeito, todavia, o que essa independência do amor com relaçáo à contrapartida diz de sua essência temporal enquanto admissão de passado e futuro em sua propriedade originária. Se o amor é cura/cuidado, radica-se na temporalidade de ser-no-mundo com os outros.

Isso significa, concretamente, que nos "planos para agradar o amado" não se planeja o agrado do outro, como se se estivesse planejando um investimento, determinado segundo expectativas de lucro futuro. Para investimentos, cabem as interferências da escolha previamente calculada em vista de um futuro determinado. Os "planos para agradar o amado", por sua vez, não vão além do próprio momento presente em que o agrado deve acontecer, no qual o amante se projeta e no qual vive a cada etapa da construçáo desse momento - pode-se afirmar que o amado "vive para isso", como quem planeja uma festa com amor, não tendo em vista quem irá comparecer, falar bem ou falar mal, ou quaisquer outras formalidades sociais, ou o mero ocupar-se da "administração de um evento", mas a certeza de que será um “belo acontecimento”. Ou seja, "viver para isso" significa não ter em "conta" a repercussão, mas realizar-se no processo que se esgota no momento "para o qual" se viveu, no qual se vinha vivendo pelo amor. Trata-se de um continuum, não há a interposição de mais nada. Eis tudo o que pode significar, para um amor verdadeiro, querer o amor 
do outro: não a espera pelo que pode dele receber ou nele provocar, mas o estar presente ao seu acontecer, tê-lo junto ao próprio amor - nisso o amor não passa a "valer a pena"; nisso, o amor se consagra como relação, pois o encontro aconteceu e fez-se espetacular. Aí, o objeto amado é superado, deixando de ser visto como pessoa de carne e osso, frágil mortal, para ser contemplado em sua beleza máxima e infinita como amante eterno. Escreve Heidegger a Arendt, em 1 de maio de 1925: "O direito à espera é para o amado o mais maravilhoso, pois justamente na espera a amada se faz 'presente.." (HEIDEGGER apud LUDZ, 2001 , p. 20 [Doc. 13]). Não se poderia ainda tomar essa espera, em sua autenticidade - considerando o que também escreve Heidegger a respeito, em Ser e tempo -, como uma espera pensante, como o autêntico sentido do "pensar no que se ama"? A ausência do pensado como condiçáo de seu ser propriamente pensado também é reconhecida por Arendt (1987, p. 227):

Em sua separação essencial em relação ao mundo, o pensar sempre se dedica apenas ao ausente, a questóes ou coisas subtraídas à percepção imediata. Se, por exemplo, encontra-se um homem face a face, ele é percebido de fato em sua corporeidade, mas não se pensa nele. Se se pensa, já se interpóe um muro entre os que se encontram, secretamente se distancia o contato imediato. Para se aproximar pelo pensar de uma coisa ou, antes, de um homem, eles devem se manter distantes da percepção imediata. ${ }^{9}$

$\mathrm{Na}$ impossibilidade de se concluir, no sentido de dar por encerrado, ainda que provisoriamente, o assunto, contando, porém, que o exposto até aqui tenha aberto caminhos não apenas para uma compreensão mais originária do amor, mas também da pertinência de seu sentido ao centro das meditaçóes de Heidegger, resta abrir horizontes. Se o amor não é um sentimento, mas uma relação posta por si mesma (compelindo/impelindo) à revelia de quem ama e de quem é amado, ainda não se esclareceu como isso é possível, tampouco por que Heidegger não o tematizou. A alternativa para compreendê-lo será examinar o amor como uma disposiçáo, no sentido que lhe dá Heidegger, em sua analítica existencial, uma vez que já estejamos "autorizados" a considerar o amor, no contexto de Ser e tempo e para além dele, não mais como simples tonalidade afetiva. Enquanto disposiçáo, o amor não apenas colocaria a si mesmo como relação essencial entre o homem e seu mundo, como também, e mais importante, poderíamos chegar à compreensão de que o mundo se transforma aos olhos de quem ama, a ponto de, adquirindo sentido peculiar,

9 Uma versão do texto foi enviada a Heidegger por carta, em setembro de 1969 (v. LUDZ, 2001, p. 137). 
as açốes e a própria vontade entrarem em conformidade à disposição amorosa. "O amor não apenas transforma o conhecer, mas também o sentir. Ele não é um conhecimento, mas uma total transformação daquilo que significa conhecer. [...] Esta força transformadora chama-se favor." (SCHUBACK, 2012a, p. 148). É por amor que eclodem certos sentimentos e não outros, que as próprias tonalidades afetivas emergem como modos seus. A esta altura, a pergunta de Heidegger a Arendt - "nas cartas espelha-se a obra... ou será que vale antes o contrário?" - talvez tenha como resposta: "elas se correspondem...”

MORAES, D. The relevance of the original meaning of love to the main horizon of Martin Heidegger’s thought. Trans/form/ação, Marília, v. 41, n. 2, p. 137-156, Abr./Jun., 2018.

\begin{abstract}
Although studies on love in Heidegger's works are rare, the question can be approached in many ways. This paper aims to discuss one aspect of the question, perhaps the most comprehensive. After a brief consideration of existing works on Heideggerian love, we start from the perspective that love is not a kind of "central concept" in Heidegger's work, but that the meaning of love is central for his concept of philosophy. Restricting our discussion to this point, however, should not let us forget a more essential understanding, which is that love not only refers to the thinking attitude, but comprehends Heidegger's entire discussion of our mode of being; from the latter emerges the problem of philosophy and philosophy as problem. We then proceed to examine the existing correspondence between this more general consideration and the question of relations of love among human beings.
\end{abstract}

KEYwORDs: Love. Freedom. Sorge. Forthcoming. Favoring.

\title{
REFERÊNCIAS
}

AGAMBEN, G. La passion de la facticité. In: AGAMBEN, G.; PIAZZA, V. L'ombre de l'amour: le concept d'amour chez Heidegger. Paris: Payot \& Rivages, 2003.

ARENDT, H. Martin Heidegger faz oitenta anos. In: ARENDT, H. Homens em tempos sombrios. Tradução de Denise Bottmann. São Paulo: Companhia das Letras, 1987. p. 221-230.

. O conceito de amor em Santo Agostinho: ensaio de interpretação filosófica.

Tradução de Alberto Pereira Dinis. Lisboa: Instituto Piaget, 1997.

CAMUS, A. La peste. [S.I.]: Gallimard, 2005.

FERNANDES, M. A. O cuidado como amor em Heidegger. Revista de Abordagem Gestáltica, Instituto de Treinamento e Pesquisa em Gestalt-terapia de Goiânia, Goiânia, v. XVII, n. 2, p. 158-171, jul./dez. 2011. 
FERREIRA, A. M. C. Amor e liberdade em Heidegger. Kriterion: Revista de Filosofia UFMG. Belo Horizonte, v. LII, n. 123, p. 139-158, jan./jun. 2011.

HEIDEGGER, M. Que é isto - a Filosofia? In: HEIDEGGER, M. Conferências e escritos filosóficos. Tradução de Ernildo Stein. Sáo Paulo: Nova Cultural, 2000a. p. 21-40.

- Serenidade. Tradução de Maria Madalena Andrade e Olga Santos. Lisboa:

Instituto Piaget, [2000b].

La pobreza. Apresentação de Philippe Lacoue-Labarthe. Tradução de Irene Agoff. Edição bilíngue alemão-espanhol. Buenos Aires: Amorrortu, 2006.

. O que quer dizer pensar? Tradução de Gilvan Fogel. In: HEIDEGGER, M. Ensaios e conferências. 4. ed. Petrópolis: Vozes; Bragança Paulista: EDUSF, 2007a. p. 111-124.

. “... poeticamente o homem habita...”. Tradução de Marcia Sá Cavalcante Schuback. In: HEIDEGGER, M. Ensaios e conferências. 4. ed. Petrópolis: Vozes; Bragança Paulista: EDUSF, 2007b. p. 165-181.

- Nietzsche. V. I. Tradução de Marco Antônio Casanova. Rio de Janeiro: Forense Universitária, 2007c.

. Sobre o humanismo. In: HEIDEGGER, M. Marcas do caminho. Tradução de Enio Paulo Giachini e Ernildo Stein. Revisão de Marco Antônio Casanova. Petrópolis: Vozes, 2008. p. 326-376.

. Seminários de Zollikon: protocolos - diálogos - cartas. Ed. Medard Boss. Tradução de Gabriella Arnhold e Maria de Fátima de Almeida Prado. Revisão de Maria de Fátima de Almeida Prado e Renato Kirchner. 2. ed. rev. Petrópolis: Vozes; Bragança Paulista: EDUSF, 2009.

. Meditação. Tradução de Marco Antônio Casanova. Petrópolis: Vozes, 2010.

- Interpretaçôes fenomenológicas sobre Aristóteles: introdução à pesquisa fenomenológica. Tradução de Enio Paulo Giachini. Petrópolis: Vozes, 2011.

- A essência da liberdade humana: introdução à filosofia. Tradução de Marco Antônio Casanova. Rio de Janeiro: Via Verita, 2012.

. Ser e tempo. Tradução de Marcia Sá Cavalcante Schuback. 9. ed. Bragança Paulista: EDUSF; Petrópolis: Vozes, 2014.

LANCELIN, A.; LEMONNIER, M. Os filósofos e o amor: de Sócrates a Simone de Beauvoir. Rio de Janeiro: Agir, 2009.

LUDZ, U. (Org.). Hannah Arendt-Martin Heidegger: correspondência 1925-1975. Tradução de Marco Antonio Casa Nova. Rio de Janeiro: Relume Dumará, 2001.

MORAES, D. O absurdo do amor e da morte: perplexidade e indignação diante da finitude em duas obras de Ingmar Bergman. In: CARVALHO, J. M. (Org.). SEMANA 
DE FILOSOFIA: FILOSOFIAS DA EXISTÊNCIA E FENOMENOLOGIA, 7. 2004. São João del-Rei. Atas... São João del-Rei: UFSJ, 2005. p. 55-70.

PIAZZA, V. L'amour en retrait. In: AGAMBEN, G.; PIAZZA, V. L'ombre de l'amour: le concept d'amour chez Heidegger. Paris: Payot \& Rivages, 2003.

RATCLIFFE, M. The phenomenology of mood and the meaning of life. In: GOLDIE, P. (Ed.). The Oxford handbook of philosophy of emotion. Oxford: Oxford University Press, 2009. p. 349-371.

SCHOPENHAUER, A. Aforismos para a sabedoria de vida. Tradução de Jair Barboza. São Paulo: Martins Fontes, 2009.

SCHUBACK, M. S. C. Heideggerian love. In: BORNEMARK, J.; SCHUBACK, M. S. C. (Ed.). Phenomenology of eros. Huddinge: Södertörns Högskola, 2012a. p. 129-152.

. Vida privativa ou vida lacunar? Uma possível resposta de Heidegger à fenomenologia da vida de Renaud Barbaras. Cadernos Espinosanos: Estudos Sobre o Século XVII, Departamento de Filosofia da FFLCH-USP, São Paulo, n. XXVII, p. 71-93, jul./ dez. 2012 b.

. Amor (Liebe) [verbete]. Tradução de Marcia S. Cavalcante Schuback e Dax Moraes. Princípios: Revista de Filosofia, PPGFIL/UFRN, Natal, v. 22, n. 38, p. 361-368, maio/ago. 2015.

Recebido: 14/07/2016

Aprovado: 16/06/2017 